\title{
The Rise of Digital Citizenship and the Participatory Museum
}

\author{
Ann Borda \\ Centre for the Digital Transformation of Health \\ University of Melbourne \\ Australia \\ aborda@unimelb.edu.au
}

\author{
Jonathan P. Bowen \\ School of Engineering \\ London South Bank University \\ United Kingdom \\ jonathan.bowen@lsbu.ac.uk
}

\begin{abstract}
In the paper, we explore the notion of digital citizenship, particularly with respect to museums and cultural organisations. Digitally literate citizens are more often able to engage on the Internet as part of one or more online communities. We start by considering some examples of pioneering digital citizenship before the term became widely used. We then survey some more current examples and how museums can adapt to this development for the benefit of all. Digital citizenship related to other phenomena such as citizen science and citizen journalism. Being a good digital citizen involves a certain level of digital literacy, and also altruism, but the necessary literacy increasingly prevalent as digital technology and culture spreads around the world.
\end{abstract}

Citizen journalism. Citizen science. Digital citizenship. Digital culture. Digital literacy. Online museums.

\section{BACKGROUND}

This paper follows on from a study about public participation in research in museums and cultural organisations (Borda \& Bowen 2020). A focus of the study was the application of citizen science approaches, particularly using crowdsourcing and other participatory practices (Borda et al. 2019). We extend this research to explore further the role of digital citizenship in the cultural sector. Digital citizenship can be defined as (Costello 2020):

"the responsible use of technology and etiquette pertaining to an online presence. This includes behaviours and responses to others within a digital community in which one is a member."

Digital citizenship has gained traction in the cultural sector in the last couple of years and manifests itself in several contexts, for example citizen journalism, citizen science, etc. This can be an issue in the context of large social media giants (Viadhyanathan 2018) and national governments (Schneider 2018), both of which can wield vast power relative to individual citizens. Here we consider some of the issues in the context of museums and digital culture (Giannini \& Bowen 2019a; 2019b).

Digital literacy, a major cornerstone of digital citizenship. Paul Gilster first popularised the term digital literacy in his book of the same name, published in 1997. He conceived of digital literacy as, simply, "literacy for a digital age" (Gilster 1997). Since Gilster's coining of the phrase, there have been a number of updated definitions in line with the shifting advancements of all things digital, but a common understanding is that digital literacy is clearly evolving into the "capability to use digital technology and knowing when and how to use it." (Ribble \& Bailey 2007).

Digitally literate citizens are more often able to engage on the Internet as part of one or more online communities, such as citizen scientists tackling data collection and/or open data related activities through collective and individual efforts (Borda et al. 2019; Borda \& Bowen 2020). A critical aspect of such digital citizenship practice is the continuous development of norms of appropriate, responsible, and empowered technology use. These norms are encapsulated by Mark Ribble in nine elements (Ribble 2017; Ribble \& Bailey 2007). The timely significance of these norms has been highlighted in the rise of "fake news", as we discuss later.

The emergent role of digital citizenship and its relationship to the cultural sector is illustrated with these and other supporting examples, including a review of challenges and future developments. 


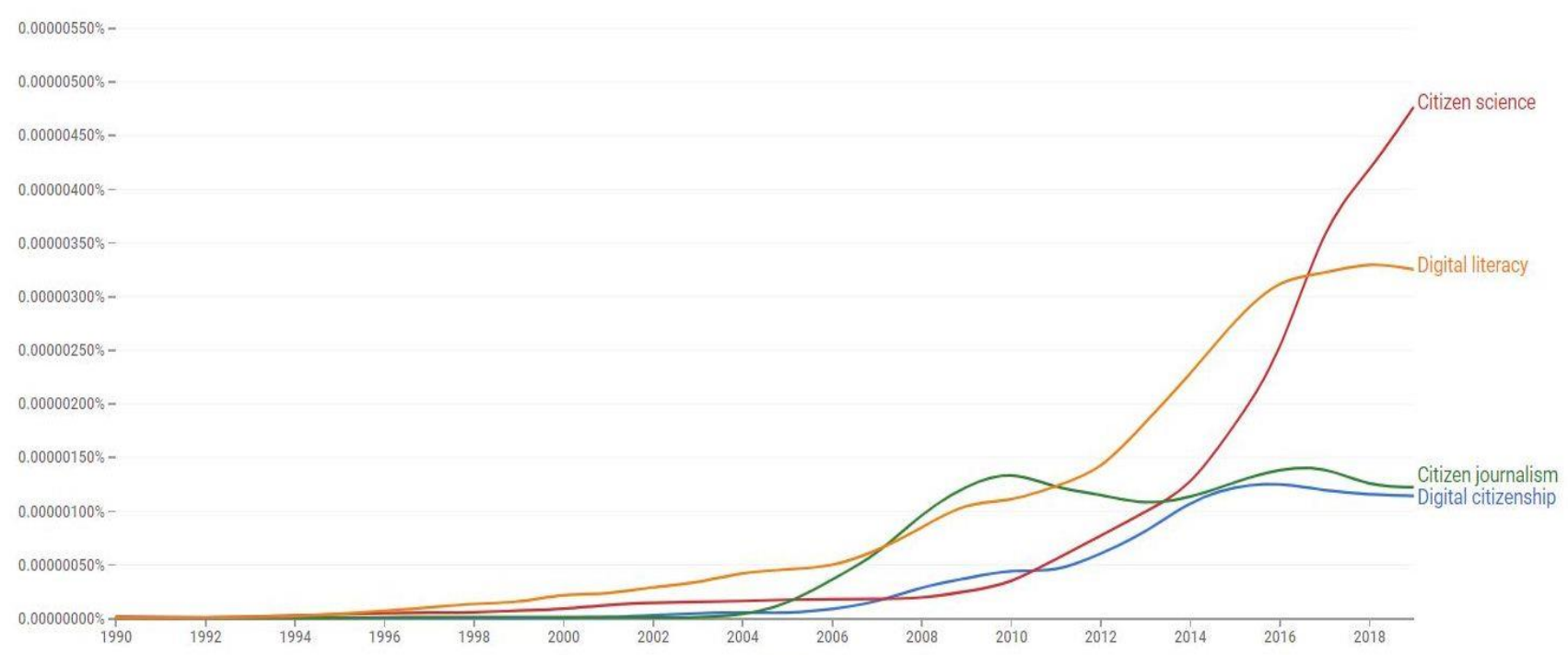

Figure 1: Frequency of terms in books. (https://books.google.com/ngrams, Google Books Ngram Viewer.)

\section{DIGITAL CITIZENSHIP PIONEERS}

The term "digital citizenship", "digital citizen" (Wikipedia 2021), and other related terms, have only come into use in recent years. "Digital citizenship" is broadly defined as the ability to participate in society online (Mossberger 2007) and this concept has manifested itself in other associated terms. Figure 1 illustrates the change in use of some of the terms relating to this paper. The terms "citizen science" (Irwin 1995) and "digital literacy" (Gilster 1997) have gained usage from the early 1990s, as the World Wide Web developed (Berners-Lee 1999), with "citizen science" still rising rapidly in popularity (Hecker et al. 2018). The terms "citizen journalism" (Allan \& Thorsen 2009) and "digital citizenship" (Mossberger et al. 2007; Hintz et al. 2018) have only gained traction this century, the later rising slower that the former, but the two terms are now of approximately equal popularity.

The concepts of digital citizenship have been around for a while, although initially for only a very small proportion of the population. Relatively early in the development of the Internet, especially as email increased, the concept of "netiquette" developed (Negroponte 1995, pp.191-193). In the early days with limited bandwidth, brevity was important. There is a story that the Stanford computer scientist Donald Knuth gave up email in the mid-1980s, after about ten years of email use, reasoning that a decade of email was enough for anyone in their lifetime. Even then, spam email was on the increase for anyone with a high profile in the digital world. Nowadays, there are other issues than bandwidth of concern for the digital citizen, for text at least, such as the proliferation, recognition, and passing on of "fake news" (Miller 2018), etc.

The issues concerning digital citizenship have been especially studied with respect to education (Ribble
2015; Rogers-Whitehead 2019), but less so in relation to museums. Being a digital citizen involves different information literacy skills than traditional media (Simsek \& Simsek 2013) and developing these skills is a lifelong (Kurbanoğlu et al. 2014) process, especially as digital technology develops so rapidly. The balance of "digitality" and reality is something that all citizens in a technology-driven society must increasingly negotiate (Bowen \& Giannini 2014; 2021), including with respect to museums (Giannini \& Bowen 2019c). Museum professional themselves need appropriate digital skills as well (Giannini \& Bowen 2015).

Good digital citizenship involves some altruism. Perhaps one of the most extreme examples was the invention and establishment of the World Wide Web by Tim Berners Lee (1999) for now great financial gain, giving $t$ away to the world. Without his ability to convince CERN to do this, we may all be using Microsoft-controlled protocols for some Web equivalent, but even Bill Gates recognised when he was beaten and supported the web instead.

Another act of generosity by Tim Berners-Lee (1999, p. 59) was the establishment of the Virtual Library in the early 1990s with his colleague Arthur Secret, to help with the navigation of the web before search engines became well-established. This included early information on and links to online museum resources in the Virtual Library museums pages (VLmp), an international; collaborative volunteer effort (Bowen 1995a; 1995b; Gaia et al. 2020). VLmp itself included the Virtual Museum of Computing (VMoC), which linked to an Alan Turing home page (https://www.turing.org.uk) by Andrew Hodges, the definitive biographer of Alan Turing (Hodges 1983). These were early 1990s examples of an online 
museum and information provision started by individuals (Bowen et al. 2005).

More recently, the online encyclopaedia Wikipedia (https://www.wikipedia.org) has been another example of the altruism of a digital citizen, Jimmy Wales (Reagle \& Koerner 2020), formerly a financial trader. This is now the best place for digital citizens to create and edit information on museums online (Bowen \& Angus 2006), replacing the likes of VLmp and the Virtual Library, with a much grander international multi-language collaboration. The underlying "wiki" technology can be used directly by museums to encourage collaboration by digital citizens (Bowen 2008) and enable crowdsourcing (Liu \& Bowen 2011).

Digital citizenship can involve campaigning, for those that are expert in the use of social media. One example involves Bletchley Park, formerly the centre for World War II codebreaking operations by Alan Turing et al. (Copeland et al. 2017), and now a heritage site and museum. Social media, especially Twitter was used to help raise awareness of the site and difficulties in fundraising (Black et al. 2010; Black \& Colgan 2015).

Good digital citizenship is important in building virtual communities, both in general (Borda \& Bowen 2011), and in the context of museums (Beler 2004). It can enable people with different skillsets to come together with a common goal, often on a volunteer basis. A common purpose is important and this can be studied in the social science Community of Practice (CoP) framework (Wenger 1998; Wenger et al. 2002), that is useful in modelling how communities in a specific area become established, develop, and eventually transmogrify or die depending on their ultimate success. See, for example, the community around the EVA London conference itself (Bowen 2020), necessarily becoming completely digital during the Covid pandemic.

Digital citizenship can also be helpful in local communities as well as more widespread ones. Witness the efforts of Ingrid Beazley at Dulwich Picture Gallery in south London, with the help of others (Beazley et al. 2010). She was central to the establishment of a local online magazine blog, Dulwich OnView (https://dulwichonview.org.uk), that continues to this day with regular articles of local interest.

More controversially, digital citizenship may involve protest and activism. The \#MeToo movement has affected museums (Giannini 2019; Giannini \& Bowen 2019d), requiring the increasing need for political correctness if controversy is to be avoided. While this was initially a Western movement is it now become increasingly international, including in
China for example, where the 'Weiguan' culture of avoiding direct involvement in events has still had an effect in the digital world (Han \& Bowen 2021).

\section{REPOSITIONING DIGITAL CITIZENSHIP AND MUSEUMS}

The rise of digital citizenship has timely significance for museums and their positioning as participatory knowledge organisations. Leading cultural organisations, such as the American Alliance of Museums and the UK Museums Association, engage in high-profile advocacy and campaign programs, encompassing larger social issues impacting digital citizenry across racism, homelessness, and migration, among other challenges.

\begin{abstract}
"Museums help us negotiate the complex world around us; they are safe and trusted spaces for exploring challenging and difficult ideas." (MA 2018, p. 4).
\end{abstract}

This close relationship has been particularly highlighted in the context of "fake news" which came into prominence following the 2016 US election. The viral propagation of misinformation online and in social media (e.g., Twitter and Facebook) resulted in museums, galleries, and libraries in the US, UK, and worldwide responding by holding a series of 'Day of Facts' campaigns (DayOfFacts 2017) on 17 February 2017, targeting a range of myths about science, history, and climate change (Adorno n.d.). See the Facts Matter initiative at Chicago's Field Museum in Figure 2.

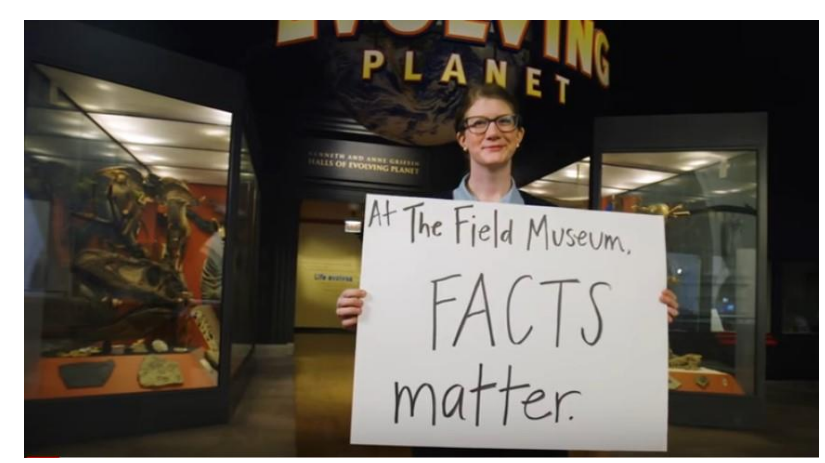

Figure 2: Facts Matter at The Field Museum. (https://www.youtube.com/watch?v=jdMfPn6bpio, YouTube, April 2017.)

The international social media campaign reinforced the positioning of cultural organisations as trusted public sources of information and knowledge (Dilenschneider 2017). Government agencies in the US similarly responded through their own media channels to promote evidence-based news. The staff of the scientific agency National Oceanic and Atmospheric Administration (NOAA) in the US, for example, created an alternative Twitter account (altNOAA n.d.) - the "unofficial persistence team of 
the NOAA" to publish climate change and weather data and related news at no taxpayers' expense.

There are continuing efforts in the cultural and government sectors to combat misinformed 'facts' and stories through exhibitions and policy-facing strategies (Miller 2018), such as museums and climate justice programs (Adorno n.d.). The Community Virtual Library represents a proactive community example which established a Digital Citizenship Museum (CVL n.d.) with the expressed mission to ensure citizens are digitally literate through education, raising awareness, and building community around the challenges and solutions of digital literacy.

An extension to digital literacy is the ability for the digital citizen to navigate the field of emerging technologies such as artificial intelligence (Al), and to comprehend their social implications, for instance (Ceccaroni et al. 2019). In The Coded Gaze exhibition (Nxt 2021), the Nxt Museum in the Netherlands has partnered with the Algorithmic Justice League to illuminate the socio-ethical and economic implications, e.g. facial recognition, using personal narratives and empirical research.

However, the prospect for a wider public to participate as digital citizens can also amplify the challenges of digital access and the issues of equitable distribution of technology and resources. At a basic level, the participation of citizens and enterprises in the information society depends on access to information and communication technologies such as computers, Internet networks, and mobile phones (OECD 2018).

The COVID-19 pandemic has highlighted a digital divide and critical need for digital inclusion within the cultural sector. According to a UNESCO report, institutions that had 'invested heavily' in digital activities prior to the pandemic, provided a vital resource to those who could access these (UNESCO 2020). For millions of citizens globally, especially in developing countries, access to culture through digital capabilities remains out of reach. Almost half of the world's population does not have access to the Internet and there is a persistent gender gap in terms of access to digital technologies with 327 million fewer women than men able to access the mobile Internet (OECD 2018).

In an Australian study of 73 cultural institutions, preliminary findings focused on how digital inclusion affected this cultural sector during COVID-19. Among the report findings it was uncovered that cultural sector experiences of digital exclusion are different in terms of capacity in which national and state institutions had far greater capacity than smaller public, university and artist- run institutions to deliver digital activities (Holcombe-James 2021).

Notwithstanding such differences in capacity, museums and cultural organisations share common capabilities in enabling participation at different audience levels. The Participatory Museum (Simon 2010) outlines approaches designed to aid museums in becoming more open to participation, involving users to inform, co-design programs and exhibitions, and innovate projects, as well as providing platforms for users to construct their own meanings (Boiano et al. 2019; Mutibwa et al. 2020). In the concept of the social museum, Visser recognizes new models of digital socialization between the museum and public (Visser 2013), with ways to learn with respect to broadening digital citizen engagement.

This repositioning of museums in embracing new types of participation increases the opportunities for their communities to share, be challenged, and evolve with them. In tandem with grass-roots media, open data and ubiquitous technologies, citizen-led participation has also signalled a significant shift in the ways collecting, disseminating, and sharing of information are undertaken by digital citizens (Pepi 2014). Crowdsourced heritage and citizen science approaches have flourished in these environments in which the public have contributed to curatorial tasks, such as labelling, text annotation, and gathering new observational data around their local environments (Ridge 2014; Borda et al. 2019; Borda \& Bowen 2020). The Smithsonian Open Access portal (Smithsonian n.d.) is an example of an initiative that provides a trusted and freely accessible resource supporting digital citizen enquiry and self-directed learning. Thus far, it offers more than 3 million images from the Smithsonian collections across the Smithsonian's 19 museums, nine research centres, libraries, archives, and the National Zoo.

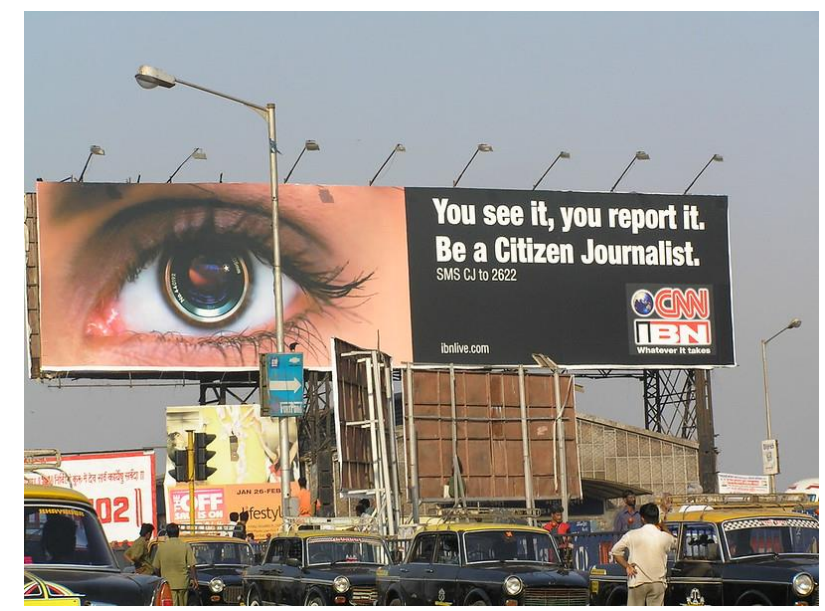

Figure 3: A citizen journalist billboard in India. (https://flickr.com/photos/sambrook/100538533, rsambrook, 13 February 2005, CC BY-NC-SA 2.0.) 
Concurrently, citizen journalism (see Figure 3) can be considered as part of this participatory evolution, starting with the personal 'weblog' (or 'blog' for short), a term coined in 1997 by Jorn Barger, who edited a general-interest website called Robot Wisdom with a daily log of curated web links (Barger 2007). Citizen journalism has since become an alternative form of news gathering and reporting by the public outside traditional structures publishing on the Internet and through social networks like Facebook and Twitter. Through citizen journalism, the digital citizen can gain an empowered position during an event, media, or history (Dangerfield 2015).

The Autry Museum of the American West, based in Los Angeles, California, created the Autry Citizen Journalism Project 'zine' (see Figure 4) to enable this empowerment by recognising the role of citizen journalism in local community storytelling and issue resolution (Autry 2018). This approach further provided a means to attract a greater diversity of communities, particularly Hispanic and other underrepresented cultural groups. The zine is issued as a bi-lingual publication in Spanish and English.

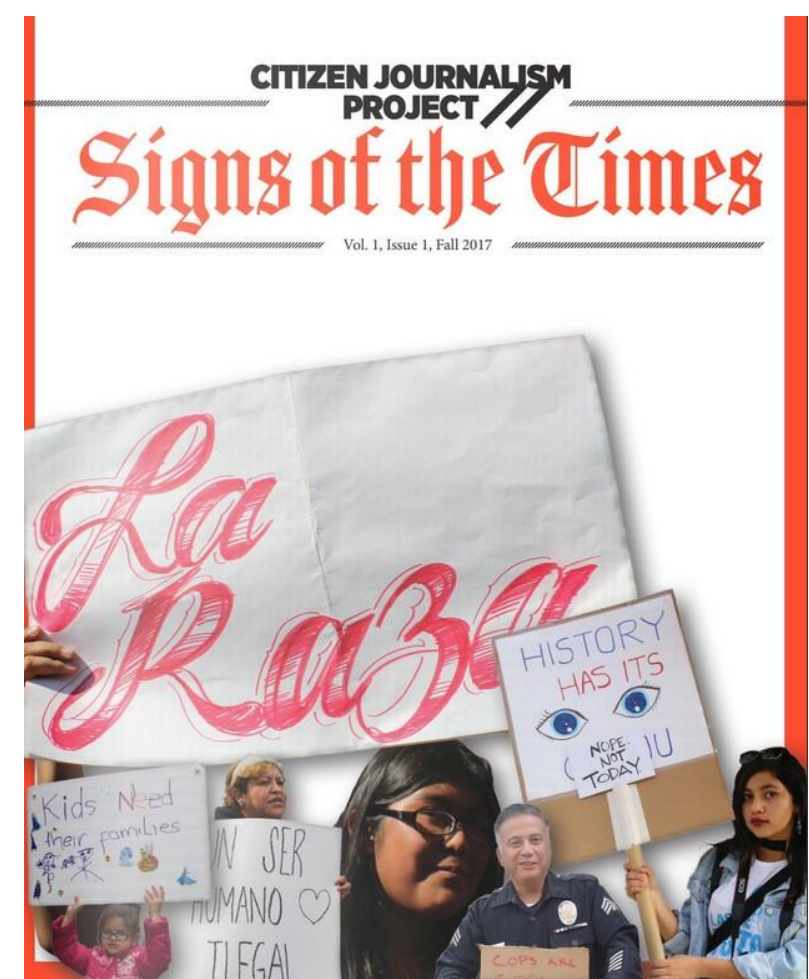

Figure 4: Cover of the Signs of the Times citizen journal series produced by the Autry Museum, Los Angeles. First issue cover, vol 1, issue 1, Fall 2017. (https://theautry.org/citizen-journalism, open access.)

A key challenge in participatory practice in museums is the audiences who participate may be a similar demographic or even less diverse than those who visit (Bonacchi et al. 2020). Evaluation and other measures need to be considered in order to understand the reach of museums and in engaging a wider range of digital citizens, including culturally and age diverse audiences (Jones \& Mitchell 2016). Museums and libraries similarly have a capability role in supporting digital literacy through the provision of education and skills as an integrated part of their programming.

\section{CONCLUSION}

Museums and cultural organisations, as trusted independent institutions, have the potential to be relevant, socially-engaged spaces for digital citizens, learning from there visitors as part of the process (Bowen \& Giannini 2019). However, they also need to be transparent in the process in order to support an environment of mutual trust to enable perspectives and learnings to be shared, and not least to facilitate a shared understanding of the aims and ethos of the underlying activity, and the context of the participants.

This process might entail a greater democratization of authority which can foster both a greater breadth of participation and richer opportunities for digital citizenry to take place. The larger challenges that we all share might be a promising place in which we could be united (Janes 2015):

"to look at the future of our community and make us reflect and rethink what it is to be a human being in the 21st century" (Adorno n.d.).

\section{Acknowledgements}

Ann Borda received an Expert Visit grant in 2019 as part of the EU Horizon 2020 funded EPIC project. Jonathan Bowen is grateful to Museophile Limited for financial support.

\section{REFERENCES}

Adorno, F. (n.d.) Stronger Than the Storm: Museums in the Age of Climate Change. Western Museums Association (WMA), USA. URL: https://westmuse.org/articles/stronger-stormmuseums-age-climate-change

Allan, S. and Thorsen, E. (eds.) (2009) Citizen Journalism: Global Perspectives. Peter Lang Publishing.

altNOAA (n.d.) @altNOAA. Twitter. URL: https://twitter.com/altNOAA

Autry (2018) Citizen Journalism: Sign of the Times. The Autry Museum, Los Angeles, USA. URL: https://theautry.org/citizen-journalism

Barger, J. (2007) Top 10 Tips for New Bloggers From Original Blogger Jorn Barger. Wired, 15 December 2007. URL:

https://www.wired.com/2007/12/blog-advice/ 
Beazley, I., Bowen, J. P., Liu, A. H.-Y., and McDaid, S. (2010) Dulwich OnView: An art museum-based virtual community generated by the local community. In A. Seal, J. P. Bowen, and K. $\mathrm{Ng}$ (eds.), EVA London 2010: Electronic Visualisation and the Arts, pp. 79-86. BCS, Electronic Workshops in Computing. DOI: 10.14236/ewic/EVA2010.14

Beler, A., Borda, A., Bowen, J. P., and FilippiniFantoni, S. (2004) The building of online communities: An approach for learning organizations, with a particular focus on the museum sector. In J. Hemsley, V. Cappellini, and G. Stanke (eds.), EVA 2004 London Conference Proceedings, University College London, UK, pp. 2.1-2.15. URL: https://arxiv.org/abs/cs/0409055

Berners-Lee, T. (1999) Weaving the Web. Orion Business Books.

Black, S., Bowen, J. P., and Griffin, K. (2010) Can Twitter Save Bletchley Park? MW 2010: Museums and the Web Conference, Denver, Colorado, USA. https://www.museumsandtheweb.com/biblio/can t witter save bletchley park.html

Black, S. and Colgan, S. (2015) Saving Bletchley Park. London: Unbound.

Boiano, S., Borda, A., and Gaia, G. (2019) Participatory innovation and prototyping in the cultural section: A case study. In J. Weinel, J. P. Bowen, G. Diprose, and N. Lambert (eds.), EVA London 2019: Electronic Visualisation and the Arts, pp. 18-26. BCS, Electronic Workshops in Computing. DOI: $10.14236 /$ ewic/EVA2019.3

Bonacchi, C., Bevan, A., Keinan-Schoonbaert, A., Pett, D., and Wexler, J. (2019). Participation in heritage crowdsourcing. Museum Management and Curatorship, 34(2), pp. 166-182. DOI: 10.1080/09647775.2018.1559080

Borda, A. and Bowen, J. P. (2011) Virtual collaboration and community. In Information Resources Management Association (ed.), Virtual Communities: Concepts, Methodologies, Tools and Applications, chapter 8.9, pp. 2600-2611. IGI Global. DOI: 10.4018/978-1-60960-100-3.ch809

Borda, A. and Bowen, J. P. (2020) Turing's Sunflowers: Public research and the role of museums. In J. Weinel, J. P. Bowen, G. Diprose, and N. Lambert, (eds.), EVA London 2020: Electronic Visualisation and the Arts. BCS, eWiC, pp. 32-39. DOI: $10.14236 /$ ewic/EVA2020.5

Borda, A., Gray, K., and Downie, L. (2019) Citizen Science Models in Health Research: an Australian Commentary. Online Journal of Public Health Informatics, 11(3), e23, December. DOI: 10.5210/ojphi.v11i3.10358
Bowen, J. P. (1995a) The Virtual Library of museums. In G. Day (ed.), Museum Collections and the Information Superhighway, 10 May 1995, Science Museum, London.

Bowen, J. P. (1995b) Collections of collections. Museums Journal, 95(8), pp. 24-25, August.

Bowen, J. P. (2008) Wiki software and facilities for museums. In D. Bearman and J. Trant (eds.), MW2008: Museums and the Web 2008, Montreal, Canada, Archives \& Museum Informatics. URL: http://www.archimuse.com/mw2008/papers/bowen/ bowen.html

Bowen, J. P. (2020) A personal view of EVA London: Past, present, future. In J. Weinel, J. P. Bowen, G. Diprose, and N. Lambert (eds.), EVA London 2020: Electronic Visualisation and the Arts. BCS, eWiC, pp. 8-15. DOI: 10.14236/ewic/EVA2020.2

Bowen, J. P. and Angus, J. (2006) Museums and Wikipedia. MW2006: Museums and the Web, Albuquerque, Archives \& Museum Informatics. URL:

https://www.archimuse.com/mw2006/papers/bowen /bowen.html

Bowen, J. P., Bennett, J., Borda, A., Hodges, A., Filippini-Fantoni, S., and Beler, A. (2005) The development of science museum websites: Case studies. In L. T. W. Hin and R. Subramaniam (eds.), E-learning and Virtual Science Centers, Section 3: Case Studies, Chapter XVIII, pp. 366392. Idea Group Publishing. DOI: 10.4018/978-159140-591-7.ch018

Bowen, J. P. and Giannini, T. (2014) Digitalism: The new realism? In $\mathrm{K}$. Ng, J. P. Bowen, and $\mathrm{S}$. McDaid (eds.), EVA London 2014: Electronic Visualisation and the Arts. BCS, eWiC, pp. 324331. DOI: $10.14236 /$ ewic/eva2014.38

Bowen, J. P. and Giannini, T. (2019) The Digital Future of Museums. In Giannini \& Bowen (2019a), chapter 28, pp. 551-577. DOI: 10.1007/978-3-31997457-6 28

Bowen, J. P. and Giannini, T. (2021) Digitality: A reality check. In Weinel et al. (2021), this volume.

Ceccaroni, L., Bibby, J., Roger, E., Flemons, P., Michael, K., Fagan, L., and Oliver, J. L. (2019) Opportunities and risks for citizen science in the age of artificial intelligence. Citizen Science: Theory and Practice, 4(1), p. 29. DOI: 10.5334/cstp.241

CVL (n.d.) Digital Citizenship Museum. Community Virtual Library. URL:

https://communityvirtuallibrary.org/digitalcitizenship-museum/ (accessed 28 February 2021).

Copeland, B. J., Bowen, J. P., Sprevak, M., Wilson, R. J., et al. (2017) The Turing Guide. Oxford University Press. 
Costello, C. (2020) Digital Citizenship. Virtual Library, 1 October 2020. URL: https://www.virtuallibrary.info/digital-citizenship.html Dangerfield, M. B. (2015) Power to the People: The rise and rise of Citizen Journalism. Tate, UK. URL:https://www.tate.org.uk/art/artterms/p/photojournalism/power-people

DayOfFacts (2017) \#DayOfFacts - Museums and cultural/ scientific institutions reminding the public that facts matter. WordPress. URL: https://dayoffacts.wordpress.com

Dilenschneider, C. (2017) People Trust Museums More Than Newspapers. colleendilenschneider, 26 April 2017. URL:

https://www.colleendilen.com/2017/04/26/peopletrust-museums-more-than-newspapers-here-iswhy-that-matters-right-now-data/

Gaia, G., Boiano, S. Bowen, J. P., and Borda, A. (2020) Museum websites of the first wave: The rise of the virtual museum. In J. Weinel, J. P. Bowen, G. Diprose, and N. Lambert (eds.), EVA London 2020: Electronic Visualisation and the Arts, this volume. BCS, Electronic Workshops in Computing.

Giannini, T. (2019) Contested Space: Activism and Protest. In Giannini \& Bowen (2019a), chapter 5, pp. 91-111. DOI: $10.1007 / 978-3-319-97457-65$

Giannini, T. and Bowen, J. P. (2015) A New York Museums and Pratt partnership: Building Web collections and preparing museum professionals for the digital world. MW2015: Museums and the Web, Chicago, USA, 8-11 April 2015. URL: https://mw2015.museumsandtheweb.com/paper/anew-york-museums-and-pratt-partnership-buildingweb-collections-and-preparing-museumprofessionals-for-the-digital-world/

Giannini, T. and Bowen J. P. (eds.) (2019a) Museums and Digital Culture: New perspectives and research. Springer, Series on Cultural Computing. DOI: 10.1007/978-3-319-97457-6

Giannini, T. and Bowen, J. P. (2019b) Digital Culture. In Giannini \& Bowen (2019a), chapter 1, pp. 3-26. DOI: $\underline{10.1007 / 978-3-319-97457-61}$

Giannini, T. and Bowen, J. P. (2019c) Museums and Digitalism. In Giannini \& Bowen (2019a), chapter 2, pp. 27-46. DOI: 10.1007/978-3-31997457-6 2

Giannini, T. and Bowen, J. P. (2019d) Art and activism at museums in a post-digital world. In $\mathrm{J}$. Weinel, J. P. Bowen, G. Diprose, G., and N. Lambert (eds.) (2019) EVA London 2019: Electronic Visualisation and the Arts. BCS, eWiC, pp. 27-35. DOI: 10.14236/ewic/EVA2019.4

Gilster, P. (1997) Digital Literacy. New York: John Wiley.
Gleason, B. and von Gillern, S. (2018) Digital citizenship with social media: Participatory practices of teaching and learning in secondary education. Educational Technology \& Society, 21(1), pp. 200-212.

Han, B. and Bowen, J. P. (2021) The Weiguan Culture Phenomenon in Chinese Online Activism. In Weinel et al. (2021), this volume.

Hecker, S., Haklay, M., Bowser, A., Makuch, Z., Vogel, J., and Bonn, A. (eds.) (2018) Citizen Science: Innovation in Open Science, Society and Policy. London: UCL Press.

Hintz, A., Dencik, L., and Wahl-Jorgensen, K. (2018) Digital Citizenship in a Datafied Society. Polity.

Hodges, A. (1983) Alan Turing: The Enigma. New York: Simon and Schuster.

Holcombe-James, I. (2021). COVID-19, digital inclusion, and the Australian cultural sector: A research snapshot. Digital Ethnography Research Centre, RMIT University, Melbourne, Australia. DOI: $\underline{10.25916 / j a v a-w k 29}$

Janes, R. R. (2015) The End of Neutrality: A Modest Manifesto. Informal Learning Review, 135, pp. 3-8, November-December. WordPress. URL: https://coalitionofmuseumsforclimatejustice.files.wo rdpress.com/2017/08/the-end-of-neutrality-ilrarticle-dec-2015.pdf

Jones, L. M. and Mitchell, K. J. (2016) Defining and measuring youth digital citizenship. New Media \& Society, 18(9), pp. 1817-1839. DOI:

$\underline{10.1177 / 1461444815577797}$

Irwin, A. (1995) Citizen Science: A study of people, expertise and sustainable development. London: Routledge.

Kurbanoğlu, S., Špiranec, S., Grassian, E., Mizrachi, D., and Catts, R. (eds.) (2014) Information Literacy: Lifelong Learning and Digital Citizenship in the 21st Century. Springer, Communications in Computer and Information Science, volume 492. DOI: 10.1007/978-3-31914136-7

Liu, A. H.-Y. and Bowen, J. P. (2011) Creating online collaborative environments for museums: $A$ case study of a museum wiki. International Journal of Web Based Communities, 7(4), pp. 407-428. DOI: 10.1504/IJWBC.2011.042988

MA (2018) Museums Taskforce Report and Recommendations. Museums Association, London, UK. URL: https://maproduction.ams3.digitaloceanspaces.com/app/uplo ads/2020/08/17073208/Museums-TaskforceReport-and-Recommendations.pdf 
Miller, P. (2018) A new mission for museums: Report calls for institutions to help battle 'fake news'. The Herald, 5 March 2018. URL:

https://www.heraldscotland.com/news/16064183.ne w-mission-museums-report-calls-institutions-helpbattle-fake-news/

Mossberger, K., Tolbert, C. J., and McNeal, R. S. (2007) Digital Citizenship: The Internet, Society, and Participation. The MIT Press.

Mutibwa, D. H., Hess, A., and Jackson, T. (2020) Strokes of serendipity: Community co-curation and engagement with digital heritage. Convergence, 26(1), pp. 157-177. DOI:

$\underline{10.1177 / 1354856518772030}$

Negroponte, N. (1995) Being Digital. Hodder \& Stoughton.

Nxt (2021) The Coded Gaze: Equitable and accountable Al. Nxt Museum, The Netherlands. URL: https://nxtmuseum.com/artist/the-coded-gaze/

OECD. (2018) Bridging the Digital Gender Divide: Include, Upskill, Innovate. Organisation for Economic Co-operation and Development. URL: http://www.oecd.org/digital/bridging-the-digitalgender-divide.pdf

Pepi, M. (2014) Is a Museum a Database?: Institutional Conditions in Net Utopia. E-flux Journal, 60, December 2014. URL: https://www.eflux.com/journal/60/61026/is-a-museum-adatabase-institutional-conditions-in-net-utopia/

Reagle, J. and Koerner, J. (eds.) (2020) Wikipedia @ 20. The MIT Press.

Ribble, M. (2015) Digital Citizenship in Schools: Nine Elements All Students Should Know, $3^{\text {rd }}$ edition. International Society for Technology in Education.

Ribble, M. (2017) Digital Citizenship: Using technology appropriately. URL:

https://www.digitalcitizenship.net

Ribble, M. and Bailey, G. (2007) Digital Citizenship in Schools. Washington, DC: ISTE.

Ridge, M. (ed.) (2014) Crowdsourcing our Cultural Heritage. London: Ashgate.
Rogers-Whitehead, C. (2019) Digital Citizenship in Schools: Teaching Strategies and Practice from the Field. Rowman \& Littlefield Publishers.

Schneider, F. (2018) China's Digital Nationalism. Oxford University Press.

Simon, N. (2010) The Participatory Museum. URL: http://www.participatorymuseum.org/

Simsek, E. and Simsek, A. (2013) New Literacies for Digital Citizenship. Contemporary Educational Technology, 4(2), pp. 126-137.

Smithsonian (n.d.) Smithsonian Open Access. Smithsonian Institution, Washington, D.C., USA. URL: https://www.si.edu/openaccess

UNESCO (2020). UNESCO Report: Museums around the world in the face of COVID-19. https://unesdoc.unesco.org/ark:/48223/pf00003735 30

Vaidhyanatham, S. (2018) Antisocial Media: How Facebook Disconnects Us and Undermines Democracy. Oxford University Press.

Visser, J. (2013) From Social Media to the Social Museum. Nordic Center of Heritage Learning. Ostersund, Sweden. URL: http://nckultur.org/wpcontent/uploads/2013/06/From Social Media to a Social Museum Jasper Visser.pdf

Weinel, J., Bowen, J. P., Borda, A., and Diprose, G. (eds.) (2021) EVA London 2021: Electronic Visualisation and the Arts. BCS, Electronic Workshops in Computing (eWiC). ScienceOpen. DOI: $10.14236 /$ ewic/EVA2021.0

Wenger, E. (1998) Communities of Practice: Learning, Meaning, and Identity. Cambridge University Press.

Wenger, E., McDermott, R. A., and Snyder, W. (2002) Cultivating Communities of Practice: $A$ Guide to Managing Knowledge. Harvard Business School Press.

Wikipedia (2021) Digital citizen. Wikipedia. URL: https://en.wikipedia.org/wiki/Digital citizen 